\author{
В.М. Пилипенко ${ }^{1}$, А.В. Гончарук ${ }^{2}$, Л.М. Крючка ${ }^{3}$ \\ ${ }^{1}$ Харківський національний університет Повітряних Сил ім. І. Кожедуба, Харків \\ ${ }^{2}$ Воєнно-дипломатична академія ім. С. Березняка, Київ \\ ${ }^{3}$ Національний університет оборони України ім. І. Черняховського, Київ
}

\title{
ІНСТРУМЕНТАРІЙ УПРАВЛІННЯ ТАЛАНТАМИ В КАДРОВОМУ МЕНЕДЖМЕНТІ ЗБРОЙНИХ СИЛ УКРАЇНИ
}

У статті розглянуто етапи управління талантами та етапи управління кар'єрою військовослужбовців. Доведено, щчо основною метою управління талантами є підготовка резерву талановитих співробітників на ключові посади для використання їх в перспективі, щзо в певній мірі відповідає меті управління кар'срою військовослужбовців. Розглянуто основні інструменти управління талантами, за якими відбувається залучення, збереження, утримання і розвиток персоналу. Визначені інструменти управління талантами в кадровому менеджменті Збройних Сил Украйни та умови для їх запровадження.

Ключові слова:інструменти управління талантами, кадровий резерв, кадровий менеджмент, управління кар'єрою,управління талантами.

\section{Вступ}

Постановка проблеми. В провідних країнах світу вже на протязі двох десятиріч для успішної роботи з НіРо-співробітниками (з високим потенціалом, від англ. High Potential) застосовується система управління талантами. В Збройних Силах України управління талантами не знайшло такого застосування, натомість застосовують систему управління кар'єрою, яка є складовою системи кадрового менеджменту (системи управління персоналом) та спрямована на оптимальне виконання завдань щодо забезпечення потреб Збройних Сил у людських ресурсах та застосування індивідуального підходу до кожної особи, іiі розвитку, кар'єрного зростання та використання відповідно до призначення. Залишення у лавах Збройних Сил професіоналів, пошук та залучення найкращих талантів визначено Міністерством оборони України безперечним пріоритетом нової військової кадрової політики [1]. Виникає необхідність визначити інструменти системи управління талантами, які можна адаптувати до збройних сил та застосовувати в системі управління персоналом в Збройних Силах України.

Аналіз останніх досліджень і публікацій. Різні напрямки наукових досліджень у галузі управління талантами походять саме від закордонних дослідників, а тому першими вони мали місце практичного застосування у міжнародних компаніях. Концептуальний підхід до управління талантами запропонований такими авторами: Д. Джой-Меттьюз, Д. Меггінсон, М. Сюрте [2], М. Орт, М. Еффрон [3], Е. Майклз, Е. Хендфілд-Джонс, Е. Екселрод [4] та інші. Серед досліджень, присвячених рекрутингу талантів, прикладом цікавої роботи є книга Д. Анде- рса "Рідкісна знахідка: як помітити талант раніше всіх" [5], що описує, як визначити людей з видатним потенціалом. Велика увага приділяється питанням мотивації талантів. Серед таких робіт праці М. Баттеріс і Б. Ройтер [6], А. Клочкова [7].

Робіт щодо досліджень питань управління талантами в збройних силах нами не знайдено. Роботи вітчизняних дослідників у військовому кадровому менеджменту присвячені в основному питанням удосконалення системи оцінювання (атестування) військовослужбовців та формування кадрового резерву.

Мета статті - визначити інструментарій управління талантами, який можна використовувати в кадровому менеджменті Збройних Сил України під час управління кар'єрою військовослужбовців 3 високим потенціалом.

\section{Виклад основного матеріалу}

3 кожним днем зростає інтерес керівництва компаній і наукових співтовариств до вивчення феномена управління талантами. В той же час не існує однозначної визначеності даного терміну. Про це свідчить велика кількість статей та наукової літератури, в яких різні фахівці дають різне визначення поняттю управління талантами. Армстронг М. в своїх працях дає визначення “управління талантами це застосування інтегрованої сукупності видів діяльності, спрямованих на те, щоб організація приваблювала, утримувала, мотивувала і просувала талановитих співробітників, яких вона потребує зараз і в майбутньому. Мета управління талантами - забезпечити приплив талантів, оскільки вони є основним ресурсом організаціі” [8]. Майклз Е., Хенфілд- 
Джонс Х., Екселрод Е. стверджують, що управління талантами - це діяльність організацій, що дозволяє використовувати вкладення в талановитий персонал в області середнього та топ менеджменту [4]. Хілтон Д. розглядає управління талановитими співробітниками, як набір індивідуалізованих управлінських практик для співробітників з високим потенціалом або кадрового резерву [9]. Карташов С.А., Одегов Ю.Г., Шаталов Д.В. дають своє визначення управління талантами - це спроба спрогнозувати, які людські ресурси знадобляться організації, і створити умови для їх сучасного залучення [10].

В області управління талантами поняття “талант” розглядається 3 точки зору управлінського сенсу слова, отже, під поняттям “талант” необхідно розуміти співробітника з високим потенціалом (рі- вень розвитку компетенцій) і продуктивністю (результати роботи).

Виходячи 3 цього, пропонується використовувати термін управління талантами, запроваджений Девідом Уоткинсом 3 Softscape, який вперше був використаний в його статті, опублікованій в 1998 році і в подальшому розвинутий в його книзі “Системи управління талантами” в 2004 році. Управління талантами (англ. talent management) - сукупність інструментів управління персоналом, які дають можливість організації залучати, ефективно використовувати і відтворювати якості співробітників, які дозволяють їм вносити істотний внесок в розвиток організації.

Основні етапи управління талантами представлені на рис. 1.

\begin{tabular}{|c|c|}
\hline & $\frac{\text { ідентифікація (виявлення) талантів серед працівників компан }}{\text { формування активної стратегії пошуку талантів }}$ \\
\hline & $\begin{array}{c}\text { використання нестандартних методів залучення талантів у } \\
\text { компанію }\end{array}$ \\
\hline & $\begin{array}{c}\text { визначення ключових факторів привабливості компанії для } \\
\text { залучення талантів }\end{array}$ \\
\hline \multirow{7}{*}{$\begin{array}{c}\text { Етапи } \\
\text { управління } \\
\text { талантами }\end{array}$} & $\begin{array}{c}\text { формування системи «вирощування» управлінських кадрів, } \\
\text { розвиток та управління лідерством }\end{array}$ \\
\hline & $\begin{array}{c}\text { розробка планів розвитку та професійних досягнень талантів, } \\
\text { способів та методів іх утримання в компаній }\end{array}$ \\
\hline & $\begin{array}{c}\text { планування кар'єрного заміщення, професіиних ротацій та } \\
\text { спадкоємності серед талановитих працівників }\end{array}$ \\
\hline & $\begin{array}{c}\text { забезпечення процесу безперервного навчання і розвитку } \\
\text { талантів }\end{array}$ \\
\hline & формування активної комунікаційної атмосфери \\
\hline & $\begin{array}{c}\text { створення диференційованої системи оплати праці талановитих } \\
\text { працівників }\end{array}$ \\
\hline & $\begin{array}{c}\text { постійні інвестиції в розвиток талантів, підвищення їх } \\
\text { кваліфікації та мобільності }\end{array}$ \\
\hline
\end{tabular}

Рис. 1. Етапи управління талантами

3 метою планування кар'єрного заміщення, професійних ротацій та наступництва талановитих працівників зараховують до кадрового резерву для подальшого навчання і розвитку.

Управляти талантами - значить утримувати високоефективних (висококваліфікованих) співробітників, створюючи їм умови для того, щоб вони відчували задоволеність своєю роботою.

Таким чином, управління талантами - це цілеспрямована діяльність компанії по створенню, розвитку і використанню ряду талановитих, висококваліфікованих співробітників, які здатні точно, ініціативно, своєчасно та ефективно вирішувати складні завдання.
Це не програма або проект, а система, яка функціонує в режимі безперервного пошуку і відбору талановитих співробітників, їх оцінки та призначення, підвищення мотивації всіх співробітників організації до ефективної роботи.

Під системою управління талантами необхідно розуміти сукупність інструментів, спрямованих на залучення (підбору, відбору і найму), збереження (адаптації, організації та створення комфортних i безпечних праці), утримання (мотивації та оцінки) i розвиток (навчання, формування кадрового резерву, службове просування) персоналу.

Практиці управління талантами у світових компаніях притаманні інструменти, представлені на рис. 2. 


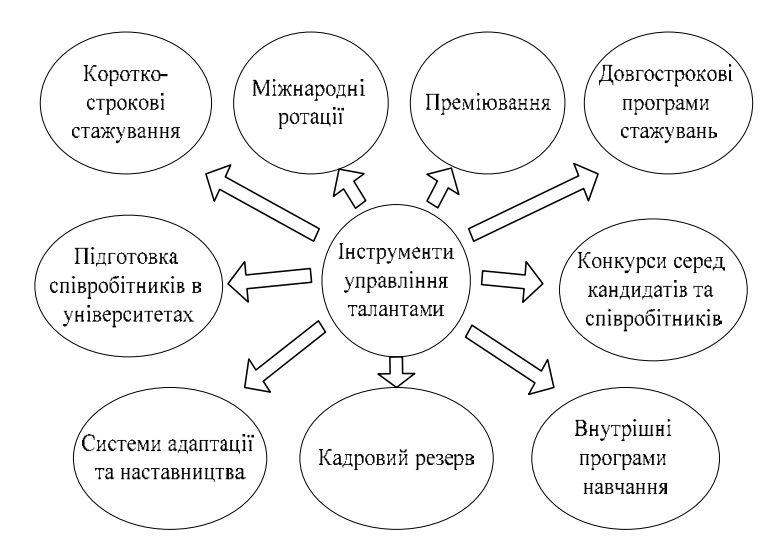

Рис. 2. Інструменти управління талантами

Основні інструменти управління талантами, за якими відбувається залучення, збереження, утримання і розвиток персоналу, наведені в табл. 1.

Таблиця 1

Інструменти управління талантами

\begin{tabular}{|c|c|c|}
\hline $\begin{array}{l}\text { № } \\
3 / \Pi\end{array}$ & $\begin{array}{c}\text { Напрямки роботи } \\
\text { в управлінні } \\
\text { талантами } \\
\end{array}$ & Інструменти \\
\hline \multirow[t]{6}{*}{1.} & \multirow[t]{6}{*}{ залучення } & стипендії \\
\hline & & $\begin{array}{c}\text { короткострокові } \\
\text { стажування }\end{array}$ \\
\hline & & $\begin{array}{c}\text { довгострокові } \\
\text { програми стажувань }\end{array}$ \\
\hline & & міжнародні ротації \\
\hline & & $\begin{array}{c}\text { підготовка співробітників } \\
\text { в університетах }\end{array}$ \\
\hline & & $\begin{array}{c}\text { конкурси серед } \\
\text { кандидатів і співробітників }\end{array}$ \\
\hline \multirow[t]{2}{*}{2.} & \multirow[t]{2}{*}{ збереження } & $\begin{array}{c}\text { системи адаптації } \\
\text { та наставництва }\end{array}$ \\
\hline & & кадровий резерв \\
\hline \multirow[t]{6}{*}{3.} & \multirow[t]{6}{*}{ утримання } & преміювання \\
\hline & & кадровий резерв \\
\hline & & міжнародні ротації \\
\hline & & $\begin{array}{c}\text { підготовка співробітників } \\
\text { в університетах }\end{array}$ \\
\hline & & $\begin{array}{c}\text { довгострокові програми } \\
\text { стажувань } \\
\end{array}$ \\
\hline & & $\begin{array}{c}\text { конкурси серед кандидатів } \\
\text { і співробітників }\end{array}$ \\
\hline \multirow[t]{6}{*}{4.} & \multirow[t]{6}{*}{ розвиток } & $\begin{array}{c}\text { довгострокові програми } \\
\text { стажувань }\end{array}$ \\
\hline & & $\begin{array}{c}\text { внутрішні програми } \\
\text { навчання } \\
\end{array}$ \\
\hline & & кадровий резерв \\
\hline & & міжнародні ротації \\
\hline & & $\begin{array}{c}\text { підготовка співробітників } \\
\text { в університетах }\end{array}$ \\
\hline & & $\begin{array}{c}\text { конкурси серед кандидатів } \\
\text { і співробітників }\end{array}$ \\
\hline
\end{tabular}

Питанню розвитку та утриманню талантів у збройних силах не приділяється достатньої уваги. Підвищення бойових можливостей сучасного озброєння, створення високотехнологічних роботизованих систем, перенесення боротьби (протистояння) у кіберпростір вимагає залучення високоінтелектуальних фахівців до лав збройних сил з високим потенціалом розвитку. Пошук, залучення та утримання даних фахівців в системі кадрового менеджменту потребує синтезу системи управління талантами в систему управління кар'єрою.

Управління кар'єрою - комплекс заходів, що здійснюється відповідними командирами (начальниками) та службами персоналу з планування, організації, здійснення і контролю проходження військової служби військовослужбовцями 3 урахуванням їх особистих якостей і досягнень [11].

Етапами управління кар'єрою військовослужбовців $€$ :

- вивчення кандидатів на військову службу за контрактом;

- прийняття на військову службу за контрактом на підставі встановлених вимог;

- планування кар'єри військовослужбовців 3 урахуванням потреб Збройних Сил України та побажань військовослужбовців;

- аналіз виконання заходів планування кар'єри військовослужбовців;

- коригування індивідуальних планів управління кар'єрою військовослужбовців;

- проведення періодичного оцінювання військовослужбовців.

Основною метою управління кар'єрою військовослужбовця $є$ ефективне використання його потенціалу під час проходження служби шляхом індивідуального підходу до кожного військовослужбовця та чітке розуміння військовослужбовцями своєї подальшої перспективи та службової кар'єри.

Військовослужбовці, які досягли позитивних результатів у професійній діяльності, відповідають визначеним вимогам та відібрані для цілеспрямованої підготовки з метою подальшого просування на вищі посади за результатами періодичного оцінювання, зараховуються до кадрового резерву.

Однією зі складових системи управління кар'єрою є впроваджена система оцінювання (атестування) військовослужбовців, результати якої становлять основу для прийняття кадрових рішень, забезпечуючи оцінку відповідності займаним посадам та ефективності виконання посадових обов'язків. Від результатів комплексного (щорічного) оцінювання військовослужбовців залежить якість процедури добору та розстановки на посади, формування резерву кандидатів для просування по службі [12], визначення перспективи службового використання військовослужбовців та формування індивіду- 
альних планів розвитку кар'єри. Основні положення, порядок формування і використання резерву кандидатів для просування по службі у Збройних Силах України визначено у методичних рекомендаціях [13].

Можна зробити висновок, що основною метою управління талантами є підготовка резерву талановитих співробітників на ключові посади 3 метою використання їх в перспективі, що в певній мірі відповідає меті управління кар'єрою військовослужбовців.

В той же час, для залучення, збереження, утримання та розвитку військовослужбовців особливо складних та дефіцитних спеціальностей $є$ необхідність застосування інструментарію управління талантами в системі управління кар'єрою Збройних Сил України. Інструментами управління талантами в кадровому менеджменті Збройних Сил України можуть бути:

- короткострокові та довгострокові програми стажувань та підвищення кваліфікації військовослужбовців за напрямком фахової діяльності;

- міжнародні програми навчання;

- внутрішні програми навчання;

- системи адаптації і наставництва;

- додатковий кадровий резерв з числа талановитих військовослужбовців;

- матеріальні мотиваційні чинники (додаткове преміювання за конкретні отримані результати на посаді);

- нематеріальні мотиваційні чинники (стимулювання досягнення військовослужбовцем власних цілей розвитку).

Для запровадження вказаного вище інструментарію необхідно змістити акценти в роботі з персоналом таким чином:

- знаходяться найбільш цінні для організації співробітники, віддача від яких в управлінській або професійній діяльності значно більша, ніж від інших;
- використовується потенціал кращих фахівців вже сьогодні, не чекаючи нових призначень;

- в першу чергу фокусуються на розвитку співробітників, їх подальшому просуванні і вихованні у них почуття приналежності організації.

\section{Висновки}

Таким чином, в статті з'ясовано, що в останні роки проблематика кадрового менеджменту є тісно пов'язаною 3 науковим напрямком, який отримав назву “управління талантами”.

Управління талантами порівняно нова область досліджень у менеджменті, і в першу чергу, в управлінні людськими ресурсами. Недолік емпіричних робіт з тематики управління талантами, так само як i слабка теоретична база, дозволяє внести свій внесок у розвиток даної проблематики.

Управління талантами у Збройних Силах - це процес, який перетинається і протікає паралельно 3 іншими кадровими процесами, але акцентує увагу на певній групі співробітників і включає в себе формалізовані методи для визначення талановитих особистостей, їх пошуку, мотивації і стабілізації. Запропоновані інструменти управління талантами повинні бути адаптовані до Збройних Сил України та застосовані в системі кадрового менеджменту, а саме в системі управління кар'єрою військовослужбовців.

Для побудови ефективної системи управління кар'єрою військовослужбовців необхідно враховувати велику кількість інформації про сам об'єкт управління - персонал. Особливим інструментом отримання такого роду інформації є оцінка персоналу, що дозволяє визначати індивідуальні особливості працівників, їх сильні і слабкі сторони, мотиваційні потреби і потенційні можливості. У свою чергу, отримана інформація дозволяє забезпечувати індивідуальний, ефективний підхід для прийняття управлінських рішень, що стосуються військовослужбовців.

\section{Список літератури}

1. Залишення у Збройних Силах професіоналів, пошук та залучення найкращих талантів $є$ безперечним пріоритетом нової військової кадрової політики [Електронний ресурс]. - Режим доступу: http://www.mil.gov.ua/news/2019/12/19/zalishennya-u-zbrojnih-silah-profesionaliv-poshuk-ta-zaluchennya-najkrashhih-talantive-bezperechnim-prioritetom-novoi-vijskovoi-kadrovoi-politiki/.

2. Джой-Меттьюз Д. Развитие человеческих ресурсов / Д. Джой-Меттьюз, Д. Меггисон, М. Сюрте. - М.: Эксмо, 2006. $-432 \mathrm{c}$.

3. Орт М. Управление талантами. Краткий курс / М. Орт, М. Эффрон. - М.: Азбука-Аттикус, 2014. - 224 с.

4. Майклз Э.Н. Война за таланты / Э.Н. Майклз, Э.С. Хэндфилд-Джонс, Э.А. Экселрод. - М.: Манн, Иванов и Фербep, 2005. $-272 \mathrm{c}$.

5. Anders G. The Rare Find: How Great Talent Stands Out. Portfolio Penguin / G. Anders. - New York: Portfolio, 2011. $304 \mathrm{p}$.

6. Баттерис М. Корпоративные бриллианты: как удерживать талантливых сотрудников в компании: пер. с англ. / М. Баттерис, Б. Ройтер. - М.: Гросс Медиа, 2005. - 253 с.

7. Клочков А. КРІ и мотивация персонала. Полный сборник практических инструментов / А. Клочков. - М.: Эксмо, 2010. $-103 \mathrm{c}$. 
8. Армстронг М. Практика управления человеческими ресурсами. 10-е издание / М. Армстронг. - СПб: Питер, 2012. $-848 \mathrm{c}$.

9. Hilton D. Hiring and Retaining Top Talent / D. Hilton // Credit Union Executive Journal. - 2013. - Vol. 40, No. 5. P. 179-189.

10. Карташов С.А. Управление талантами как HR-технология / С.А. Карташов, Ю.Г. Одегов, Д.В. Шаталов // Вестн Ом. ун-та. Серия “Экономика”. - 2013. - № 1. - С. 85-94.

11. Наказ Міністерства оборони України від 20.12.2019 № 653 “Питання управління кар’єрою військовослужбовців Збройних Сил України, які проходять військову службу за контрактом”. - Режим доступу: http://www.mil.gov.ua/content/mou_orders/653_mou.pdf.

12. Методичні рекомендації з порядку організації і проведення атестування військовослужбовців Збройних Сил України, затверджені директором Департаменту кадрової політики Міністерства оборони України від 12.10.2018 № 226/4907.

13. Методичні рекомендації з порядку формування і використання Резерву кандидатів для просування по службі у Збройних Силах України, затверджені директором Департаменту кадрової політики Міністерства оборони України від 19.03.2018 № 350 .

\section{References}

1. Ministry of Defence Ukraine (2019), "Zalyshennja u Zbrojnykh Sylakh profesionaliv, poshuk ta zaluchennja najkrashhykh talantiv je bezperechnym priorytetom novoji vijsjkovoji kadrovoji polityky" [Retaining professionals in the Armed Forces, finding and recruiting the best talent is the undisputed priority of the new military personnel policy], available at: www.mil.gov.ua/news/2019/12/19/zalishennya-u-zbrojnih-silah-profesionaliv-poshuk-ta-zaluchennya-najkrashhih-talantiv-ebezperechnim-prioritetom-novoi-vijskovoi-kadrovoi-politiki.

2. Dzhoi-Mett'yuz, D., Meggison, D. and Syurte, M. (2006), "Razvitie chelovecheskikh resursov" [Human Resource Development], Moscow, $432 \mathrm{p}$.

3. Ort, M. and Effron, M. (2014), "Upravlenie talantami. Kratkii kurs" [Talent Management. Short course], Moscow, 224 p.

4. Maiklz, E.N., Khendfild-Dzhons, E.S. and Ekselrod, E.A. (2005), "Voina za talanty" [War for talents], Moscow, 272 p.

5. Anders, G. (2011), The Rare Find: How Great Talent Stands Out. Portfolio Penguin, Portfolio, New York, 304 p.

6. Batteris, M. and Roiter, B. (2005), "Korporativnye brillianty: kak uderzhivat' talantlivykh sotrudnikov $v$ kompanii" [Corporate diamonds: how to retain talented employees in a company], Moscow, $253 \mathrm{p}$.

7. Klochkov, A. (2010), "KPI i motivatsiya personala. Polnyi sbornik prakticheskikh instrumentov" [KPI and staff motivation. A complete collection of practical tools], Moscow, $103 \mathrm{p}$.

8. Armstrong, M. (2012), "Praktika upravleniya chelovecheskimi resursami" [The practice of human resource management], St, Petersburg, 848 p.

9. Hilton, D. (2013), Hiring and Retaining Top Talent, Credit Union Executive Journal, No. 5, Vol. 40, pp. 179-189.

10. Kartashov, S.A., Odegov, Yu.G. and Shatalov, D.V. (2013), "Upravlenie talantami kak HR-tekhnologiya" [Talent management as HR technology], Tomsk State University Journal. Series “Economics”, No. 1, pp. 85-94.

11. Order of the Ministry of Defense of Ukraine (2019), "Pytannia upravlinnia karieroiu viiskovosluzhbovtsiv Zbroinykh Syl Ukrainy, yaki prokhodiat viiskovu sluzhbu za kontraktom No. 653 vid 20.12.2019" [Career management issues of servicemen of the Armed Forces of Ukraine who under go military service under a contract No. 653 dated 20.12.2019], available at: www.mil.gov.ua/content/mou_orders/653_mou.pdf.

12. Department of Personnel Policy of the Ministry of Defense of Ukraine (2018), "Metodychni rekomendatsii z poriadku orhanizatsii i provedennia atestuvannia viiskovosluzhbovtsiv Zbroinykh Syl Ukrainy, zatverdzheni dyrektorom Departamentu kadrovoi polityky Ministerstva oborony Ukrainy No. 226/4907 vid 12.10.2018" [Guidelines on the organization and certification of military personnel of the Armed Forces of Ukraine, approved by the Director of the Personnel Policy Department of the Ministry of Defense of Ukraine No. 226/4907 dated October 12, 2018].

13. Department of Personnel Policy of the Ministry of Defense of Ukraine (2018), "Metodychni rekomendatsii z poriadku orhanizatsii i provedennia atestuvannia viiskovosluzhbovtsiv Zbroinykh Syl Ukrainy, zatverdzheni dyrektorom Departamentu kadrovoi polityky Ministerstva oborony Ukrainy No. 226/4907 vid 12.10.2018" [Methodological recommendations on the procedure for the formation and use of the reserve of candidates for promotion in the Armed Forces of Ukraine, approved by the Director of the Personnel Policy Department of the Ministry of Defense of Ukraine No. 350 dated March 19, 2018].

\section{Відомості про авторів:}

\section{Пилипенко Віталій Миколайович}

старший науковий співробітник

Харківського національного університету

Повітряних Сил ім. І. Кожедуба,

Харків, Україна

https://orcid.org/0000-0002-3912-4372

\section{Information about the authors:}

\section{Vitalii Pilipenko}

Senior Research Associate

of Ivan Kozhedub Kharkiv National

Air Force University,

Kharkiv, Ukraine

https://orcid.org/0000-0002-3912-4372 


\section{Гончарук Андрій Вікторович}

заступник начальника першого факультету

Воєнно-дипломатичної академії ім. Є. Березняка

3 навчальної роботи,

Київ, Україна

https://orcid.org/0000-0001-7364-0402

\section{Крючка Леонід Миколайович}

ад'юнкт

Національного університету оборони України

ім. І. Черняховського,

Київ, Україна.

https://orcid.org/0000-0001-8767-5091

\section{Andrii Goncharuk}

Deputy Head of the First Faculty

of the Yevgeny Berezniak Military-Diplomatic Academy on educational work,

Kyiv, Ukraine

https://orcid.org/0000-0001-7364-0402

Leonid Kruchka

Doctoral Student

of the National Defence University

of Ukraine named after Ivan Cherniakhovskyi,

Kyiv, Ukraine.

https://orcid.org/0000-0001-8767-5091

\title{
ИНСТРУМЕНТАРИЙ УПРАВЛЕНИЯ ТАЛАНТАМИ В КАДРОВОМ МЕНЕДЖМЕНТЕ ВООРУЖЕННЫХ СИЛ УКРАИНЫ
}

\author{
В.Н. Пилипенко, А.В. Гончарук, Л.М. Крючка
}

В статье рассмотрены этапы управления талантами и этапы управления карьерой военнослужащих. Доказано, что основной целью управления талантами является подготовка резерва талантливых сотрудников на ключевые должности для использования их в перспективе, что в определенной степени соответствует цели управления карьерой военнослужащих. Рассмотрены основные инструменты управления талантами, по которым происходит привлечение, сохранение, удержание и развитие персонала. Определены инструменты управления талантами в кадровом менеджменте Вооруженных Сил Украины и условия для их внедрения.

Ключевые слова: инструменты управления талантами, кадровый резерв, кадровый менеджмент, управление карьерой, управление талантами.

\section{TALENT MANAGEMENT TOOL IN THE PERSONNEL MANAGEMENT OF THE ARMED FORCES OF UKRAINE}

V. Pilipenko, A. Goncharuk, L. Kriuchka

The article discusses the stages of talent management and the career management stages of military personnel. It is shown that talent management is a focused activity of the company to create, develop and use a cohort of talented employees who are able to effectively solve complex business problems. This is not a program or project, but a system that operates in a continuous search and selection of talented employees, their assessment and appointment, increasing the motivation of all employees of the organization to work effectively. It is proved that the main goal of talent management is to prepare a reserve of talented employees for key positions for future use, which to a certain extent corresponds to the goal of managing a career of military personnel. Increasing the combat capabilities of modern weapons, creating high-tech robotic systems, transferring combat (confrontation) to cyberspace requires the involvement of highly intelligent specialists in the ranks of the armed forces with a high development potential. The search, attraction and retention of these specialists in the personnel management system requires the synthesis of a talent management system into a career management system. The main talent management tools for attracting, maintaining, retaining and developing staff are considered. It is concluded that talent management is a process that intersects and proceeds in parallel with other personnel processes, but focuses on a specific group of employees and includes formalized methods for identifying talented individuals, their search, labor motivation and stabilization. Some talent management tools can be adapted for the Armed Forces of Ukraine and applied in the personnel management system, namely in the career management system of military personnel. Talent management tools in the personnel management of the Armed Forces of Ukraine are identified. It is proposed how it is necessary to shift the emphasis in working with staff to implement these tools.

Keywords: talent management tools, personnel reserve, personnel management, career management, talent management. 